\title{
ТЕХНОЛОГІЇ СТИМУЛЮВАННЯ ВІЗУАЛЬНОГО МИСЛЕННЯ ПІДЛІТКІВ
}

Наукове повідомлення висвітлює проблему стимулювання візуального мислення особистості. У роботі обговорюється сутність когнітивних процесів візуалізації. Виокремлюються основні лінії аналізу явища у зарубіжній і вітчизняній літературі. Визначаються основні принципи і лінії організації розвивальної роботи з питань підвищення рівня візуальних процесів у представників молодшого, середнього і старшого підліткового віку. Розкривається зміст і структуру тренінгової програми. Презентуються результати констатувального $і$ формувального етапу дослідження $з$ питань розвитку різних аспектів візуального мислення. У статті запропоновано комплекс методів, які, дозволяють розвивати візуальні мисленнєві прочеси підлітків. Представлено систему тренінгів, ігор розвитку активності висунення гіпотези, категоріальної гнучкості, конструктивної активності візуального мислення в підлітковому вічі.

Ключові слова: візуальне мислення, змістова сфера візуального мислення, тренінги, категоріальна гнучкість, конструктивна активність візуального мислення.

Научное сообщение освещает проблему стимулирования визуального мышления личности. В работе обсуждается сущность когнитивных процессов визуализации. Выделяются основные линии анализа явления в зарубежной и отечественной литературе. Определяются основные принципы $и$ линии организачии развивающей работы по вопросам повыщения уровня визуальных процессов у представителей младшего, среднего и старшего подросткового возраста. Раскрывается содержание и структуру тренинговой программы. Представляются результаты констатирующего и формирующего этапа исследования по вопросам развития различных аспектов визуального мышления. В статье предложен комплекс методов, которые позволяют развивать визуальные мыслительные процессы подростков. Представлена система тренингов, игр развития активности 
выдвижения гипотезы, категориальной гибкости, конструктивной активности визуального мылиления.

Ключевые слова: визуальное мылиение, содержательная сфера визуального мышления, тренинги, категориальная гибкость, конструктивная активность визуального мышления.

Постановка проблеми. Необхідність впровадження нових ефективних технологій розвитку візуального мислення, пошук та розробка дієвих засобів його стимулювання є одним із важливих завдань сучасної психологічної науки та педагогічної практики. Актуальність розвитку візуального мислення, як специфічного виду розумової діяльності визначається тим, що цей процес займає особливе місце в розвитку когнітивної сфери особистості і $є$ одним із найменш досліджених інтелектуальних процесів, як у вітчизняній, так і у зарубіжній психолого-педагогічній науці.

Аналіз останніх досліджень і публікацій. У вітчизняній психолого-педагогічній науці дослідження візуального мислення проведене за декількома напрямками: вивчення механізмів та закономірностей візуальних процесів в умовах вирішення ергономічних задач в інженерній психології (В. М. Гордон, В. ІІ Зінченко, В. М. Муніпов); дослідження механізмів візуального мислення як складної функціональної системи операцій (Д. Роем [4]); визначення візуальної мови опису способів вирішення геометричних задач (І. М. Арієвич, В.В.Пєтухов); аналіз особливостей просторового мислення як окремого виду візуального процесу (I. Я. Каплунович [2; 3], I. С. Якиманська); простеження ролі візуалізації в процесі вирішення творчих задач у конструкторській діяльності (В. О. Моляко); дослідження особливостей трансформації візуального образу в художньо-графічній діяльності (С. М. Симоненко) [5], виокремлення особливостей візуальної медіакультури [6].

Формулювання цілей статті. Метою повідомлення $\epsilon$ презентація ефективної цілеспрямованої програми розвитку візуального мислення у період підліткового віку.

В основу розробки програми розвитку візуального мислення підлітків 10-15 років нами було покладено такі положення:

1. На різних стадіях онтогенезу здатність до створення образів та оперування ними змінюється за рівнем складності, що дає підставу для вивчення вікових особливостей візуального мислення.

2. Отримані нами результати дозволяють визначити рівень розвитку візуального мислення підлітків різних вікових груп.

3. Формування компонентів візуального мислення найбільш інтенсивно відбувається в процесі навчання під впливом предметного змісту учбового матеріалу, а також методів оперування ним.

4. Характер образів, що виникають у процесі обробки запропонованого стимульного матеріалу, детермінується не тільки формою та змістом наочності й вимогами задач, а й суб' єктивною вибірковістю, яка визначається особистим ставленням до об'єкта діяльності. Така суб'єктивність образа вказує на наявність індивідуальних відмінностей у візуальному мисленні різних досліджуваних, що виявляються в процесі розв’язання задач.

Враховуючи вищеозначені положення, до запропонованої нами програми розвитку візуального мислення підлітків було включено вправи, рівень складності яких зростає відповідно до віку респондентів.

Виклад основного матеріалу дослідження. Визнаючи створення образів та оперування ними як довільну й свідомо керовану суб'єктом діяльність, на підставі аналізу отриманих нами експериментальних даних, щодо характерних особливостей цієї активності, ми виокремили наступні напрямки розвитку візуального мислення підлітків: розвиток активності висування візуальних гіпотез; розвиток операціональної сфери візуального мислення шляхом активізації конструктивної активності, а також поповнення арсеналу операцій та організації їх взаємодії; розвиток категоріальної гнучкості візуального мислення шляхом збагачення образу світу, завдяки чому розширюється змістовне наповнення зорових образів; розвиток візуальної креативності; активізація аналітико-синтетичних операціональних структур мислення, що є базисом для побудови якісно нових конструкцій - образів-концептів.

Зупинимось на характеристиці виокремлених напрямків. Однією з визначальних характеристик розвинутого візуального мислення є здатність до створення нових образів та оперування ними, яка реалізується в процесі продукування візуальних гіпотез, на основі заданого стимульного матеріалу. Розв’язання задачі в образах здійснюється, переважно, з опорою на наочний матеріал. Складові задачі розглядаються в різних зв'язках та відношеннях, при цьому пошук стратегії розв'язання ведеться одночасно в різних напрямках. Важливо відзначити, що в процесі пошуку долучаються не лише логічно необхідні, але й випадкові, надлишкові зв'язки, результатом чого часто є досить несподівані рішення. Розробляючи методи активізації продуктивності висування візуальних гіпотез, необхідно пам'ятати, що образ не є продуктом пасивного відображення об'єктів дійсності. Навпаки, він як промінь виокремлює і фіксує ті якості та ознаки об'єкта, які є найбільш значущими для суб'єкта. Тому, залежно від вимог 
поставленої задачі, образ може змістовно відображати ті чи інші характеристики об'єкта. Здатність образу відображати різні сторони об'єкта забезпечує його динамічність та актуальність. Отже, нова візуальна гіпотеза виникає в результаті спеціально здійснюваних мисленнєвих перетворень, основним змістом яких $\epsilon$ не лише актуалізація образів на основі заданого стимульного матеріалу, а й їх трансформація.

Експериментальні дослідження показали, що функція побудови образу найбільше активізується в процесі розв'язання задач, які потребують неодноразового перетворення образів, що виникають. Зміст цих перетворень визначається умовами задачі, які чітко детермінують їх напрямок. Вирішення задач такого типу має своєю передумовою, нарівні зі створенням образів, їх активне використання в процесі розв'язання, тобто оперування ними. Таким чином, образи $\epsilon$ не лише засобом фіксації результатів мисленнєвого процесу, але й його оперативною одиницею. Такі образи суттєво різняться між собою як за своїм змістом, так і механізмом виникнення. Часто умови задачі вимагають переходу від одного типу образів до іншого, при цьому відбувається «перекодування» образу. Значний розвиток операційної сфери візуального мислення досягається також при розв'язанні задач, що передбачають: мисленнєву трансформацію заданого матеріалу; актуалізацію мисленнсвих образів (поза наочним сприйняттям); видозміну образів. Успішність розв'язання задач такого типу значною мірою забезпечується достатньою конструктивною активністю візуального мислення. Здатність оперування образами пов'язана з розвитком довільності мисленнєвих механізмів, а також з оволодінням спеціальними способами створення образів та маніпулювання ними.

Якщо основним змістом візуального мислення є оперування образами, то важливою умовою продуктивності даного процесу $є$ наявність достатнього запасу вихідних образів, причому чим багатшим $\epsilon$ їх змістовне наповнення, тим більше є можливостей для їх видозміни, тобто оперування ними. Образ, як зауважив С. Л. Рубінштейн, ніби «вичерпує» з об'єкта постійно новий його зміст. Тому образ завжди є індивідуальним утворенням: у ньому фіксується суб'єктивно перетворений досвід ставлення конкретної людини до даного об'єкта. В образах сконцентровано виражений основний зміст внутрішнього світу людини. Навіть найелементарніший пізнавальний акт, результатом якого є створення суб'єктивного образу, починається з ініціативи суб'єкта, детермінується його установками, цілями та намірами. Отже, індивідуальний суб'єктний досвід підлітка відіграє важливу роль у створенні образів та оперуванні ними. Розширення можливостей мислення щодо породження нових образів передбачає постійне поповнення суб'єктного досвіду. Якщо це не відбувається, то підліток використовує шаблонні, позбавлені індивідуальності образи.

Одним із чинників розвитку візуального мислення є креативність, тобто здатність суб'єкта не лише активно продукувати візуальні гіпотези, а й створювати якісно нові, оригінальні образи. На матеріалі ряду досліджень було виявлено, що створення нового забезпечується такими методами, як комбінування, аналогія, встановлення нових зв'язків та перенесення функції. Аналіз літератури показав, що найбільш поширеними мисленнєвими процесами у всіх видах творчості $\epsilon$ комбінування та аналогія, а основною операцією - порівняння. Отже, цілеспрямоване формування вказаних процесів може бути основою розвитку креативності візуального мислення. У розробці комплексу вправ для розвитку образної оригінальності нами були використані загальні принципи, активізації креативності, запропоновані Боно де Едвардом [7]:

- при виникненні проблеми потрібно визначити необхідні і достатні умови ії розв'язання;

- розвиток здатності до абстрагування від минулого досвіду: зовнішня подібність задач може загальмувати процес розв'язання;

- розвиток бачення багатофункціональності об'єкта;

- створення асоціацій шляхом поєднання протилежних ідей;

- усвідомлення домінуючої ідеї в даній галузі знання й звільнення від ії впливу.

Однією 3 характерних рис візуального образу $є$ відображення в ньому не лише ознак i властивостей об'єкта, а й просторової структури його елементів (їх взаєморозташування). Одним із методів створення таких образів є графічне моделювання, яке передбачає заміну знаком реально існуючого об’єкта; при цьому засоби індикації в деякій мірі нагадують об’єкти, які вони відображають. До таких наочних моделей належать географічні карти, плани приміщень тощо.

Під час навчання підліток знайомиться з різноманітними знаковими системами. У процесі оволодіння такими системами формується здатність до оперування знаково-символічними образами, які характеризуються специфічним набором елементів (букви, цифри) і наявністю спеціальних засобів для позначення зв'язків між ними (знаки переносу, додавання, віднімання), просторового розташування (формули хімічних елементів), взаємозалежності (знаки об'єднання, напрямку руху). На відміну від образів-моделей, знаково-символічні образи зовнішньо нічим не нагадують ті об'єкти, які вони відображають, проте мають можливість показати найбільш суттєві структурні зв'язки. 
Отже, достатній розвиток аналітико-синтетичних систем мислення, а також оволодіння навичками оперування знаково-символічними образами $є$ важливою передумовою формування якісно нових конструкцій візуального мислення - образів-концептів [1].

Виділені напрямки розвитку візуального мислення було покладено в основу програми формувального експерименту. На початковому етапі з урахуванням зазначнених напрямків ми відібрали близько 150 різних технік. Всі вони були укомплектовані відповідно до змісту задач, завдання згруповані на основі принципу поступового ускладнення. У кінцевому варіанті розроблена програма розвитку складалася із 13 занять, кожне 3 яких мало свою специфіку. Для розвитку активності продукування візуальних гіпотез, конструктивної активності, категоріальної гнучкості, оригінальності ми використовували два варіанти вправ: для підлітків 10-12 років - варіант А, для підлітків 13-15 років варіант Б. Для розвитку операціональної сфери візуального мислення ми запропонували три варіанти вправ: варіант А - для підлітків 10-12 років, варіант Б- для підлітків 12-13 років, варіант В - для підлітків 14-15 років. Тренінгові заняття проводилися в групах по 24-27 підлітків два-три рази на тиждень. У залежності від індивідуальних особливостей учасників групи заняття тривали 60-90 хвилин. Наводимо приклад таких занять.

Тренінг розвитку візуального мислення для підлітків 10-15 років.

Заняття 1. Мета: знайомство 3 учасниками експериментальної групи, визначення їх особистісних якостей. Необхідний матеріал: метод спостереження, бесіда; кольоровий проективний тест «Моя сім'я» для підлітків 10-15 років.

Хід заняття. На першому етапі заняття відбувається знайомство психолога з учасниками тренінгових занять. Кожен підліток розповідає про себе: що він любить, що вміє, чого прагне, яка форма звернення йому подобається. На другому етапі учасникам пропонується кольорова проективна методика «Моя сім'я». При цьому психолог слідкує за тим, щоб учасники групи не заважали один одному. Послідовно, по мірі виконання завдання, 3 кожним підлітком проводиться індивідуальна бесіда за змістом його малюнка.

Заняття 2. Мета: розвиток активності висування візуальних гіпотез, конструктивної активності, категоріальної гнучкості, оригінальності; розвиток аналітико-синтетичних операціональних структур візуального мислення. Необхідний матеріал: вправа-гра «Ялинка асоціацій»; вправа для розвитку операціональної сфери візуального мислення для підлітків 10-11 років; вправи для розвитку операціональної сфери візуального мислення для підлітків 12-13 років; вправа для розвитку операціональної сфери візуального мислення для підлітків 14-15 років.

Враховуючи результати дослідження С. М. Симоненко [5], щодо ролі інтуїції на всіх етапах трансформації візуального образу та методологічні положення щодо розвитку візуального мислення шляхом активізації його механізмів, зокрема, евристичності, що веде до інтуїтивних рішень, на першому етапі заняття ми використовували евристичні прийоми активізації візуального мислення, зокрема метод гірлянд випадковостей та асоціацій, який належить до групи інтуїтивно-асоціативних методі.

Алгоритм методу гірлянд випадковостей та асоціацій:

1. Вибір заданого об'єкта.

2. Визначення аналогів заданого об'єкта.

3. Вибір випадкових об'єктів.

4. Виділення ознак випадкових об'єктів. Для зручності складається таблиця ознак, де в одному стовпчику фіксуються випадкові об'єкти, а в другому - ознаки цих об'єктів.

5. Генерування ідей шляхом почергового приєднання до об'єкта та його аналогів ознак випадково вибраних об'єктів.

6. Генерування гірлянд асоціацій. Почергово з ознак випадкових об'єктів генерують гірлянди вільних асоціацій.

7. Генерування нових ідей. До елементів гірлянд аналогів об’єкта намагаються приєднати елементи гірлянд асоціацій.

8. Вибір альтернативи. Вирішується питання: продовжувати генерування гірлянд асоціацій чи їх уже достатньо для вибору корисних ідей.

9. Оцінка та вибір раціональних варіантів ідей. Серед багатьох нераціональних, безглуздих ідей, як правило, завжди знаходяться оригінальні й раціональні.

10. Вибір оптимального варіанту.

Хід заняття для підлітків 10-12 років (Варіант А.). 
На першому етапі заняття за методом гірлянд випадковостей та асоціацій проводиться гра «Ялинка асоціацій». Підліткам дається така інструкція: необхідно розширити асортимент годинникового заводу. Об'єкт модернізації - годинник.

На другому етапі пропонується тренування аналітико-синтетичної операціональної діяльності візуального мислення методом пошуку і встановлення закономірностей взаємного розташування фігур та їх елементів. Акцентується увага на тому, наскільки швидко та вірно підлітки аналізують малюнок та знаходять правильне рішення.

Хід заняття для підлітків 13-15 років (Варіант Б).

Для цього віку використовується більш складний метод генерування ідей-образів синектика. Автор методу В. Гордон зазначав, що для будь - якого творчого процесу дуже важливо вміти перетворювати незвичне у звичне і навпаки - звичне у незвичне. Люди отримують спадщину із «заморожених» образів і способів розуміння, що надають навколишній дійсності зручну звичну форму, але саме від цієї спадщини й потрібно відмовлятися при розв'язанні творчих завдань.

Найбільш ефективно завдання «розморожування» образів і способів розуміння виконує засіб символічної аналогії (СА). Щоб отримати СА, В. Гордон пропонує знайти сполучення двох слів, звичайно прикметника та іменника, котрі в короткій парадоксальній формі або у вигляді метафори охарактеризували б суть завдання чи об'єкта.

«Старшим братом» СА можна назвати оксюморон - стилістичну фігуру, що складається 3 об'єднання понять парадоксальним чином і стосується одного об'єкта.

Виходячи $з$ того, що парадокс - це ствердження й заперечення одного й того ж поняття або образу (об'єкта, явища, стану чи властивості), що має численність суттєвих ознак, для проведення гри «Ялинка асоціацій» у групі старших підлітків ми пропонуємо такий алгоритм конструювання СА й оксюморона:

1. Вибір об'єкта й подання його короткої характеристики.

2. Визначення суттєвих ознак об’єкта (до їх числа можуть входити функції та й принципи дії об'єкта).

3. Визначення протилежних ознак.

4. Підбір антонімічних пар ознак, котрі в сполученні з вибраним об'єктом складають парадоксальні конструкції.

5. Відбір 3 одержаного ряду конструкцій таких комбінацій, які дають евристичне парадоксальне зображення вибраного об'єкта.

Другий етап заняття спрямований на розвиток та корекцію операціональної сфери візуального мислення. У першій вправі для підлітків 12-13 років пропонується встановити закономірності, домалювати потрібну фігуру та виключити зайву. При виконанні другої вправи потрібно визначити правило, за яким здійснюється трансформація заданої графічної структури. Для підлітків 13-15 років ми пропонуємо використовувати 2 варіанти вправи. Підліткам дається завдання вибрати заготовку, яка найбільше підходить для виготовлення зображеної об'ємної деталі.

Для перевірки ефективності розробленої програми розвитку візуального мислення підлітків всі досліджувані, які увійшли до експериментальної групи, по закінченню тренінгових занять були діагностовані за двома методиками. 3 метою співставлення результатів, отриманих до формуючого експерименту, і після нього, було складено зведені таблиці. Результати впливу спеціально організованого навчання на розвиток візуального мислення у групах молодшого та старшого підліткового віку подані за результатами методики Торренса. У нижче наведених таблицях ми подаємо результати для двох крайніх вікових підгруп $\mathrm{M}=10$ та $\mathrm{M=15}$ років (див. табл. $1 ; 2$ )

Розглянемо, які зміни в розвитку візуального мислення підлітків виявило співставлення показників методики Торренса. Як бачимо з кількісні показники активності висування візуальних гіпотез в обох групах значно змінилися (табл. 1-2). Для визначення значущості збільшення показників активності висування візуальних гіпотез, отриманих даними групами досліджуваних, ми здійснили перевірку достовірності розбіжностей за t-критерієм Стьюдента.

Аналіз перевірки даних за цим критерієм виявив, що статистично значущими виявилися відмінності між показниками всіх груп досліджуваних $(\mathrm{p}=0,05)$. Так, для показників підлітків 10 років $\mathrm{t}=5,25(\mathrm{tKp}=2,07) ; 11$ років $\mathrm{t}=3,20(\mathrm{tKp}=2,07) ; 12$ років $\mathrm{t}=4,01(\mathrm{tKp}=2,09) ; 13$ років $\mathrm{t}=2,34(\mathrm{tKp}$ $=2,06) ; 14$ років $\mathrm{t}=2,30(\mathrm{tKp}=2,05) ; 15$ років $\mathrm{t}=2,66(\mathrm{tKp}=2,04)$. Як бачимо, в усіх групах $\mathrm{t}>\mathrm{tKp}$, що підтверджує ефективність розробленої програми щодо розвитку активності висування гіпотез підлітків 10-15 років. Таким чином, на підставі даного аналізу можемо зробити висновок, що після проведення формувального експерименту відбулося значне підвищення загальної продуктивності візуального мислення. При цьому необхідно зауважити, що найбільш істотне зростання здатності до 
висування нових візуальних гіпотез щодо невизначених перцептивних стимулів спостерігається у віці 10-12 років. Показники, представлені в (табл. 1), дають можливість розглянути вікову динаміку конструктивної активності до проведення формуючого експерименту і після нього

Показники методики Торренса (для $\mathrm{M}=10$ р.)

Таблиия 1

\begin{tabular}{|c|c|c|c|c|c|c|c|c|c|}
\hline \multirow[t]{3}{*}{$\begin{array}{l}\text { № } \\
\text { 3/II }\end{array}$} & \multirow[t]{3}{*}{$\begin{array}{c}\text { Прізвище } \\
\text { учня }\end{array}$} & \multicolumn{2}{|c|}{$\begin{array}{c}\text { Активність } \\
\text { висування гіпотез } \\
\end{array}$} & \multicolumn{2}{|c|}{$\begin{array}{c}\text { Категоріальна } \\
\text { гнучкість }\end{array}$} & \multicolumn{2}{|c|}{$\begin{array}{c}\text { Конструктивна } \\
\text { активність }\end{array}$} & \multicolumn{2}{|c|}{ Оригінальність } \\
\hline & & 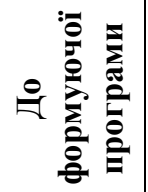 & 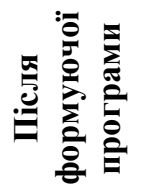 & 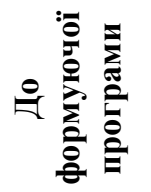 & 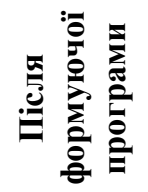 & 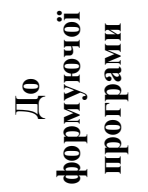 & 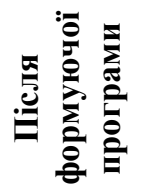 & 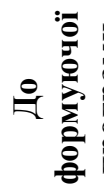 & 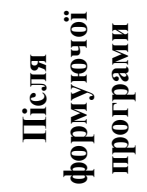 \\
\hline & & бали & бали & бали & бали & бали & бали & бали & бали \\
\hline 1 & Ж.Ю. & 22 & 28 & 15 & 20 & 41 & 48 & 38 & 45 \\
\hline 2 & Ю.Ю. & 29 & 34 & 15 & 18 & 39 & 45 & 38 & 43 \\
\hline 3 & Л.С. & 24 & 32 & 13 & 18 & 31 & 44 & 31 & 47 \\
\hline 4 & Д.С. & 23 & 30 & 14 & 16 & 38 & 50 & 32 & 40 \\
\hline 5 & M.I. & 24 & 27 & 13 & 17 & 38 & 46 & 37 & 42 \\
\hline 6 & O.I. & 26 & 30 & 15 & 19 & 38 & 44 & 33 & 42 \\
\hline 7 & К.Ю. & 21 & 29 & 9 & 14 & 32 & 47 & 28 & 39 \\
\hline 8 & Г.Л. & 27 & 34 & 14 & 18 & 40 & 47 & 26 & 34 \\
\hline 9 & C.M. & 25 & 30 & 15 & 18 & 43 & 50 & 35 & 44 \\
\hline 10 & T.Ю. & 20 & 27 & 12 & 16 & 37 & 49 & 35 & 40 \\
\hline 11 & I.B. & 18 & 28 & 11 & 17 & 27 & 45 & 39 & 43 \\
\hline 12 & K.O. & 19 & 26 & 10 & 15 & 35 & 43 & 37 & 47 \\
\hline & $\mathrm{x}$ & 23,17 & 29,58 & 13,00 & 17,17 & 36,58 & 46,50 & 34,08 & 42,17 \\
\hline & $\mathrm{b}$ & 3,33 & 2,64 & 2,09 & 1,70 & 4,58 & 2,39 & 4,17 & 3,64 \\
\hline & $\mathrm{t}$ & \multicolumn{2}{|c|}{5,25} & \multicolumn{2}{|c|}{5,42} & \multicolumn{2}{|c|}{6,66} & \multicolumn{2}{|c|}{5,06} \\
\hline \multicolumn{10}{|c|}{$\mathrm{t} \kappa \mathrm{p}=2,07 ; p=0,05$} \\
\hline
\end{tabular}

Дані показують, що здатність до складних трансформаційних перетворень значно підвищились у всіх вікових групах досліджуваних, що свідчить про ефективність впливу тренінгових занять на розвиток даної характеристики візуального мислення. Перевіривши розбіжності отриманих даних за критерієм Стьюдента, ми виявили, що статистично значущими виявилися відмінності між показниками всіх груп $(\mathrm{p}=0,05)$. Так, для підгрупи підлітків $\mathrm{M}=10$ років $\mathrm{t}=6,66 ; \mathrm{M}=11$ років $\mathrm{t}=3,59 ; \mathrm{M}=12$ років $\mathrm{t}=2,82 ; \mathrm{M}=13$ років $\mathrm{t}=5,43 ; 14$ років $\mathrm{t}=2,26 ; 15$ років $\mathrm{t}=3,76$, тобто в усіх групах $\mathrm{t}>\mathrm{tKp}$.

Особливе підвищення конструктивної активності ми визначили у підлітків 10 i 13 років, а сповільнення іï розвитку - у 12 і 14 років. Це ще раз підтверджує той висновок, що протягом досліджуваного нами вікового періоду (10-15 років) спостерігається нерівномірний розвиток візуального мислення щодо розширення можливостей операціональної сфери, але незважаючи на це, цей розвиток відбувається досить інтенсивно.

Співставлення рівня категоріальної гнучкості візуального мислення підлітків 10-15 років за критерієм Стьюдента виявили, що між показниками цих груп досліджуваних до проведення експерименту і після нього, наявна статистично значуща відмінність $(\mathrm{p}=0,05)$. Для показників у підгрупі підлітків $\mathrm{M}=10$ років $\mathrm{t}=5,42 ; \mathrm{M}=11$ років $\mathrm{t}=5,92 ; \mathrm{M}=12$ років $\mathrm{t}=3,52 ; \mathrm{M}=13$ років $\mathrm{t}=3,63 ; \mathrm{M}=14$ років $\mathrm{t}=2,70 ; \mathrm{M}=15$ років $\mathrm{t}=3,48$.

Як бачимо, помітний стрибок у розвитку гнучкості процесів переходу з рівня візуальних категорій на вербальний рівень і навпаки спостерігається у 11 річному віці. Це свідчить про нерівномірний розвиток процесів семантизації візуальних вражень.

Показники оригінальності, назви до і після формуючого експерименту вказують на наявність позитивної вікової динаміки. Підвищення результатів в усіх вікових групах є статистично значущим $(\mathrm{p}=0,05)$. Так, для показників підлітків $\mathrm{M}=10$ років $\mathrm{t}=5,06 ; \mathrm{M}=11$ років $\mathrm{t}=4,23 ; \mathrm{M}=12$ років $\mathrm{t}=7,41$; $\mathrm{M}=13$ років $\mathrm{t}=2,42 ; \mathrm{M}=14$ років $\mathrm{t}=3,48 ; \mathrm{M}=15$ років $\mathrm{t}=4,16$ 
Таблиия 2

Показники методики Торренса (для $\mathrm{M}=15$ р.)

\begin{tabular}{|c|c|c|c|c|c|c|c|c|c|}
\hline \multirow[t]{3}{*}{$\begin{array}{l}\text { № } \\
\text { 3/II }\end{array}$} & \multirow[t]{3}{*}{$\begin{array}{c}\text { Прізвище } \\
\text { учня }\end{array}$} & \multicolumn{2}{|c|}{$\begin{array}{c}\text { Активність } \\
\text { висування } \\
\text { гіпотез } \\
\end{array}$} & \multicolumn{2}{|c|}{$\begin{array}{c}\text { Категоріальна } \\
\text { гнучкість }\end{array}$} & \multicolumn{2}{|c|}{$\begin{array}{c}\text { Конструктивна } \\
\text { активність }\end{array}$} & \multicolumn{2}{|c|}{ Оригінальність } \\
\hline & & 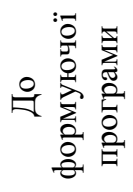 & 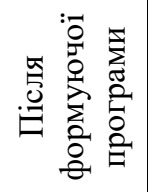 & 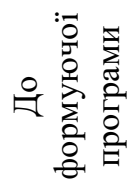 & 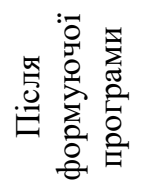 & 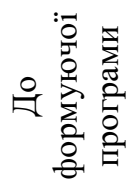 & 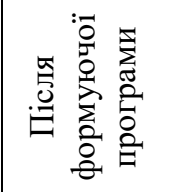 & 家 & 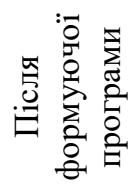 \\
\hline & & бали & бали & бали & бали & бали & бали & бали & бали \\
\hline 1 & Л.Р. & 40 & 40 & 32 & 23 & 65 & 72 & 43 & 48 \\
\hline 2 & П.Р. & 35 & 38 & 16 & 21 & 60 & 74 & 36 & 447 \\
\hline 3 & M.A. & 40 & 40 & 20 & 23 & 69 & 77 & 47 & 53 \\
\hline 4 & Л.Н. & 39 & 40 & 21 & 21 & 65 & 78 & 42 & 54 \\
\hline 5 & Ш.В. & 37 & 40 & 19 & 20 & 61 & 66 & 36 & 43 \\
\hline 6 & Я.Р. & 36 & 39 & 16 & 19 & 44 & 58 & 34 & 40 \\
\hline 7 & P.B. & 39 & 40 & 15 & 19 & 55 & 67 & 37 & 44 \\
\hline 8 & П.О. & 38 & 40 & 17 & 22 & 51 & 61 & 33 & 41 \\
\hline 9 & Ш.Т. & 37 & 40 & 15 & 17 & 58 & 63 & 37 & 49 \\
\hline 10 & T.B. & 40 & 40 & 19 & 21 & 66 & 79 & 44 & 49 \\
\hline 11 & Д.О. & 40 & 40 & 20 & 25 & 61 & 69 & 46 & 55 \\
\hline 12 & A.A. & 40 & 40 & 18 & 22 & 63 & 70 & 44 & 45 \\
\hline 13 & K.I. & 40 & 40 & 17 & 18 & 49 & 65 & 38 & 47 \\
\hline 14 & P.T. & 36 & 40 & 21 & 24 & 70 & 74 & 46 & 51 \\
\hline 15 & С.Д. & 40 & 40 & 21 & 22 & 63 & 69 & 47 & 50 \\
\hline 16 & К.В. & 40 & 40 & 18 & 20 & 70 & 81 & 40 & 44 \\
\hline & $\mathrm{x}$ & 38,56 & 39,81 & 18,38 & 21,06 & 60,63 & 70,19 & 40,63 & 47,50 \\
\hline & $\mathrm{b}$ & 1,79 & 0,54 & 2,19 & 2,17 & 7,61 & 6,72 & 4,81 & 47,49 \\
\hline & $\mathrm{t}$ & & & & 48 & & 3,76 & & ,16 \\
\hline
\end{tabular}

Доходимо висновку, що, здійснена діагностика продуктивних можливостей візуального мислення підлітків за методикою Торенса після проведення спеціально організованих занять підтвердила наявність суттєвого впливу розробленої програми на розвиток процесуальних характеристик візуальної мисленнєвої діяльності підлітків 10-15 років. Отримані результати показали, що динаміка розвитку процесуальних характеристик візуального мислення дійсно може бути змінена за умови застосування спеціальної навчальної програми.

Отже, аналіз результатів формуючого експерименту показав наступне:

1. Встановлено, що після втілення розробленої програми у всіх учасників тренінгових занять відбулися зміни в показниках розвитку процесуальних характеристик та операціональних структур візуального мислення. Наявність цих змін простежувалася у представників усієї експериментальної групи.

2. Виявлено статистично вірогідні відмінності в результативності виконання тестових завдань за методиками Торренса до і після проведення розвивального тренінгу.

Висновок. Отже, результати формувального експерименту підтвердили положення про те, що цілеспрямована організація тренінгових занять відповідно до закономірностей формування основних структурних компонентів візуального мислення виступає умовою його гармонійного розвитку. Результати формувального експерименту, які довели ефективність тренінгів розвитку візуального мислення підлітків, можуть бути цікавими для педагогів та психологів системи шкільної освіти та позашкільних закладів.

\section{Список використаних джерел}

1. Іванюта О. В. Психологічні особливості розвитку візуального мислення в підлітковому віці : автореф. дис. ... канд. психол. наук : 19.00 .07 / О. В. Іванюта ; Харків. нац. ун-т імені В. Н. Каразіна. - Харків, 2003. - 21 с.

2. Каплунович И. Я. Психологические закономерности развития пространственного мышления / И. Я. Каплунович // Вопросы психологии. - 1999. - № 1. - С. 60-66. 
3. Каплунович И. Я. О психологических различиях мышления двумерными и трехмерными образами / И. Я. Каплунович // Вопросы психологии. - 2003. - № 3. - С. 66-72.

4. Роэм Д. Визуальное мышление. Как «продавать» свои идеи при помощи визуальных образов / Д. Роэм ; пер. с англ. О. Медведь. - М. : Манн, Иванов, Фербер, Эксмо, 2013. - 300 с.

5. Симоненко С. М. Психологія візуального мислення : автореф. дис. ... д-ра психол. наук : 19.00.01 / С. М. Симоненко ; Харків. нац. ун-т імені В. Н. Каразіна. - Харків, 2005. - 38 с.

6. Череповська Н. І. Візуальна медіокультура: розвиток критичного мислення і творчого сприймання : метод. рек. / Н. І. Череповська. - Київ, МІЛЕНІУМ, 2014. - 116 с.

7. Боно де Э. Рождение новой идеи [Электронный ресурс] / Эдвард де Боно. - Режим доступа : https://ru.bookmate.com/books/Gin9Fnfh

\section{References}

1. Ivanyuta O. V. Psy`xologichni osobly`vosti rozvy`tku vizual`nogo my`slennya v pidlitkovomu vici : avtoref. dy`s. ... kand. psy`xol. nauk : 19.00.07 / O. V. Ivanyuta ; Xarkiv. nac. un-t imeni V. N. Karazina. - Xarkiv, 2003. - 21 s.

2. Kaplunovich I. Ya. Psikhologicheskiye zakonomernosti razvitiya prostranstvennogo myshleniya / I. Ya. Kaplunovich // Voprosy psikhologii. - 1999. - № 1. - S. 60-66.

3. Kaplunovich I. Ya. O psikhologicheskikh razlichiyakh myshleniya dvumernymi i trekhmernymi obrazami / I. Ya. Kaplunovich // Voprosy psikhologii. - 2003. - № 3. - S. 66-72.

4. Roem D. Vizualnoye myshleniye. Kak «prodavat» svoi idei pri pomoshchi vizualnykh obrazov / D. Roem ; per. s angl. O. Medved. - M. : Mann. Ivanov. Ferber. Eksmo, 2013. - 300 s.

5. Sy`monenko S. M. Psy`xologiya vizual`nogo my`slennya : avtoref. dy`s. ... d-ra psy`xol. nauk : 19.00.01 / S. M. Sy`monenko ; Xarkiv. nac. un-t imeni V. N. Karazina. - Xarkiv, 2005. - 38 s.

6. Cherepovs`ka N. I. Vizual`na mediokul`tura: rozvy`tok kry`ty`chnogo my`slennya i tvorchogo spry`jmannya : metod. rek. / N. I. Cherepovs`ka. - Ky`yiv, MILENIUM, 2014. - 116 s.

7. Bono de E. Rozhdenie novoy idei [Elektronnyy resurs] / Edvard de Bono. - Rezhim dostupa : https://ru.bookmate.com/books/Gin9Fnfh

\section{O. V. Ivaniuta, O. Y. Yanytska. METHODS OF VISUAL THINKING DEVELOPMENT OF ADOLESCENTS}

Scientific report highlights the problem of individual's stimulating visual thinking. Paper discusses the essence of cognitive visualization processes. The main lines of the phenomenon analysis in the foreign and domestic literature have been allocated. Basic principles and lines of developing work organization for improving the level of visual processes in the younger, middle and older adolescents have been determined. Contents and structure of the training program have been revealed. The results of ascertaining and forming stage of research in the development of various aspects of visual thinking have been presented. Article proposes a set of methods allowing development of visual thinking processes of adolescents. The system of trainings, games aimed to development of activity for promotion of a hypothesis, categorical flexibility, and constructive activity of visual thinking in adolescence which can be used by teachers and parents has been presented. Usage of mathematical statistics methods allowed confirming the effectiveness of the training program for the development of visual cognitive process.

Key words: visual thinking, semantic sphere of visual thinking, trainings, categorical flexibility, constructive activity of visual thinking. 